\title{
Crédito e Pequena Cafeicultura no Oeste Paulista: Franca/SP 1890-1914
}

\author{
Pedro Geraldo Tosi*, Rogério Naques Faleiros ${ }^{\dagger}$, Rodrigo da Silva \\ Teodoro
}

Sumário: 1. Introdução; 2. Expansão e Crise: as relações de trabalho; 3. Crédito e Acumulação: o papel da pequena cafeicultura; 4. Considerações Finais.

Palavras-chave: Cafeicultura; Pequena Propriedade; Acumulação; Trabalho; Financiamento; História de Franca/SP.

Códigos JEL: N56; N96.

Este artigo versa sobre a importância da pequena cafeicultura no complexo cafeeiro entre 1890 e 1914 . Discutimos aqui as relações de trabalho, as formas de financiamento e o modo como a pequena propriedade se insere neste universo. Utilizamos como fontes prioritárias os contratos de trabalho que envolviam a formação e/ou o trato de cafeeiros e as escrituras de dívidas hipotecárias, ambas lavradas nos Livros Cartoriais, fontes estas ainda não trabalhadas pela historiografia de forma mais sistemática. Desviamos nosso olhar para uma região marcada predominantemente pelas pequenas e médias fazendas produtoras de café, observando a dinâmica da acumulação em um período de expansão e de crise da cafeicultura.

This article turns on the importance of the small coffee production in the coffee complex economy between 1890 and 1914. We argue here the relations of work, the forms of financing and the way as the small coffee production inserts itself in this universe. We use as priority sources the employment contracts that involved the formation and/or the treatment of coffee trees and the Writes of mortgage debts, both recorded in Notarial Books, documents not used by historiography in a systematical way. We turns our look for a region marked predominantly for small and the middle producing farms of coffee, observing the dynamics of the accumulation in a period of expansion and crisis of the coffee economy.

\footnotetext{
*Professor do Departamento de Educação, Ciências Sociais e Política Internacional da UNESP - Campus de Franca. Doutor em Economia Aplicada (Área de Concentração: História Econômica) pelo Instituto de Economia da UNICAMP. E-mail: pgt os i@uol. com. br

${ }^{\dagger}$ Professor das Faculdades de Campinas - FACAMP. Doutor em Economia Aplicada. (Área de Concentração: História Econômica) pelo Instituto de Economia da UNICAMP. E-mail: roger ionaques@yahoo. com.br

${ }^{\ddagger}$ Rodrigo da Silva Teodoro cursava Doutorado em História Econômica pela FFLCH/ USP. Faleceu em junho de 2007. Dedicamos esta publicação à sua memória.
} 


\section{INTRODUÇÃO}

Grandes propriedades e grandes proprietários, infinitas lavouras de café e colônias de imigrantes a perder de vista dominam o cenário rural descrito por parte da bibliografia sobre a economia cafeeira, notadamente pelos trabalhos de cunho teórico preocupados com a formação e o desenvolvimento do capitalismo no Brasil. ${ }^{1}$ Mas a realidade do café torna-se mais complexa quando o observador debruçase sobre outros aspectos do chamado "complexo cafeeiro". Ao investigar o funcionamento do sistema de crédito, a dimensão das lavouras, as relações sociais estabelecidas entre cafeicultores de diferentes portes e as relações de produção estabelecidas na realidade rural, o pesquisador confronta-se com uma paisagem bem mais complexa e multifacetada do que poderiam prever os modelos de análise pautados em binômios do tipo "latifúndiomonocultura".

Não estamos aqui afirmando que as grandes propriedades não se situassem numa posição central na dinâmica da cafeicultura paulista, entretanto, é necessário ressaltar que as pequenas e médias lavou-

\footnotetext{
${ }^{1} \mathrm{Cf}$. Na verdade esta é uma postura mais implícita que explícita em estudos de teor abrangente, que visam demonstrar as conexões entre a acumulação na economia cafeeira e o processo de industrialização, tais como Mello (1982); Cano (1998) e Silva (1986), mas o fato de que estes trabalhos desconsideram a existência da pequena cafeicultura operando basicamente com trabalho familiar é evidente. Estudos clássicos como os de Milliet (1939) e José Francisco de Camargo (1953) evidenciam a crescente presença das pequenas propriedades (e da pequena cafeicultura) no interior paulista, notadamente nas regiões mais novas do estado, tais como a Noroeste, a Alta Paulista, a Alta Sorocabana e a Alta Araraquarense, entretanto, estes estudos não se propõem a analisar as formas de organização familiar do trabalho predominante neste "perfil de cafeicultura", melhor dizendo, as estatísticas utilizadas por ambos denotam a recorrência da pequena cafeicultura mas o universo das relações de produção estabelecidas no espaço circunscrito pela "porteira" da fazenda permanece incógnito. Os estudos sócio-geográficos de Pierre Monbeig (1949) e França (1960) também sinalizam nesta direção, mas a questão da pequena cafeicultura e sua importância para o conjunto econômico permaneceu inexplorada. Estudos de vertente marxista, como os de Martins (1979) e Sallum Jr. (1982) elegeram as formas de organização do trabalho no "oeste" paulista como objeto de análise, destacando as especificidades das relações estabelecidas entre fazendeiros e colonos. Ademais, Martins se preocupou com a "produção capitalista de relações não capitalistas de produção", enquanto Sallum Jr. concentrou seus esforços nas dualidades "proprietário/arrendatário" e "capitalista/assalariado" presentes nas relações de produção estabelecidas nas lavouras de café. Novamente percebe-se o silêncio sobre as formas de organização do trabalho familiar e a vinculação da pequena cafeicultura com o sistema de crédito. Holloway (1984) e Font (1985) exploraram a idéia de que na fronteira agrícola as condições de trabalho eram mais favoráveis aos colonos por conta do facilitado acesso a terra e de formas mais satisfatórias de remuneração, que permitiam a ascensão dos colonos à condição de proprietários. M. Font argumenta que as fases posteriores da expansão do café em São Paulo (década de 20) presenciaram o surgimento de outras formas de produção, principalmente de pequenos e médios proprietários, ligadas intimamente com as transformações políticas em curso (segundo o autor, este novo "grupo social" alcançou notória importância na plataforma eleitoral de Washington Luís para o governo de São Paulo). A hipótese central desenvolvida por estes autores é que as combinações próprias das relações de colonato permitiram a alguns colonos tornarem-se produtores independentes de mercadorias, provendo assim as bases que tornaram possivel a mudança para a produção cafeeira independente. Além de garantir sua subsistência, o direito de usufruto permitiu a produção de excedentes alimentícios que, naquele contexto de expansão da urbanização da economia paulista, se tornaria, cada vez mais, uma das fontes básicas de receita monetária. Sobre as questões da vinculação destes pequenos produtores ao sistema de crédito e da organização do trabalho pouco se avança. Vangelista (1991) realizou um abrangente estudo sobre a formação do mercado de trabalho em São Paulo, destacando que às múltiplas demandas existiam diferentes tipos de oferta de trabalho, sinalizando as extremas dificuldades para o estabelecimento de um mercado de trabalho propriamente dito. Camaradas, colonos, parceiros e assalariados urbanos (e rurais) coexistiam no complexo cafeeiro, adequando-se às diferentes ocupações organizadas pelo movimento do capital. Sobre a pequena cafeicultura, novamente, pouco se avança. Há que se destacar o esforço de Warren Dean num artigo publicado em 1976 (Dean, 1976) que aborda a questão da pequena propriedade, contudo, o autor objetivava, a partir do caso de Rio Claro, discutir as possibilidades de ascensão social dos colonos no complexo cafeeiro, concluindo que "eram modestas as proporções da mobilidade experimentadas pela massa dos imigrantes". Novamente, as relações entre pequena cafeicultura, trabalho e sistema de crédito não foram privilegiadas. De uma forma geral, nos estudos acima citados (e em outros mais), a questão das possibilidades de ascensão social dos trabalhadores rurais compõe a principal preocupação, não se discutindo as condições de manutenção (crédito) e viabilidade (trabalho) da pequena cafeicultura já constituída e ampliada com o desenvolvimento do complexo cafeeiro. Para o papel da pequena propriedade na economia escravista um bom balanço encontra-se em Marcondes (1998). O autor também mostra, por meio de um levantamento feito pelo coletor de Angra dos Reis em 1868, dos cafeicultores que exportavam pelos portos do sul da Província do Rio de Janeiro, que mesmo na produção de café, a relativa importância do pequeno produtor. Como o objetivo do autor foi demonstrar esta relativa importância da pequena propriedade, não adentra na questão da relação desta com o sistema de crédito ou seu papel na expansão cafeeira, assim como os trabalhos que cita em seu artigo.
} 
ras produtoras de café também possuíam uma grande importância nesta dinâmica, importância esta que precisa ser mensurada de uma forma mais adequada por quem se dedicar ao estudo da economia cafeeira. Em outros termos, qual é o papel da pequena cafeicultura no complexo cafeeiro? ${ }^{2}$

Reconhecemos que, para o escopo do presente trabalho, o importante é demonstrar a forma de operação da pequena cafeicultura, ou seja, minimização de relações de emprego e predominância do trabalho familiar. Uma cafeicultura operando com trabalho familiar, que se diferencia não só pelas dimensões físicas da unidade de produção, mas para a qual vários indicadores revelam, no contexto da crise 1898-1905, sua presença e sua importância e atestam maiores volumes colhidos nas safras de 1906 e $1907 .^{3}$

As fontes consultadas para a região de Franca (SP) demonstram haver aumento de cafeeiros plantados. Como entender o crescimento na quantidade de pés-de-café cultivados em um contexto de redução de preços e de restrição monetária? Isso se explica pelo acesso de famílias de reduzidas posses à propriedade agrícola (provavelmente famílias de imigrantes?) e pela operação com trabalho familiar, com conseqüente redução nos custos de produção. Para que esse argumento se sustente é necessário lembrar que uma redução de custos só aconteceria se houvesse redução nos custos de reprodução da força de trabalho, ou seja, se houvesse agricultura de alimentos conjugada à cafeicultura.

Poder-se-ia objetar que essa atividade familiar estivesse sendo direcionada ao trabalho em terras de grandes proprietários e que poderiam estar voltadas para a agricultura de alimentos, mas como sustentar esse argumento em um contexto restritivo do ponto de vista mais amplo da economia? Como sustentar tal possibilidade quando se verifica um declínio generalizado dos contratos de formação e/ou trato de cafeeiros?

A escolha do município de Franca, no interior paulista, como objeto de estudo, se deu porque historicamente esta região caracterizou-se pelo predomínio da pequena propriedade, conforme já fora destacado por Oliveira (1997) e Tosi (2003). Esta característica da cafeicultura de Franca nos permitiu analisar as formas de superação daquele contexto de restrição monetária e queda nos preços do café ao qual já aludimos de forma a captar o papel dos pequenos produtores no conjunto econômico local sem que sua atuação fosse obscurecida pela de grandes fazendeiros, que podem ter se valido de mecanismos diversos dos que analisaremos aqui para a pequena propriedade para resistir aos abalos da economia cafeeira em outras regiões.

\section{EXPANSÃO E CRISE: AS RELAÇÕES DE TRABALHO}

Não havia grandes fazendeiros em Franca, já que o maior, em 1901, Doutor João de Faria, possuía apenas 185.000 pés (Teodoro, 2006, 81), quantidade incomparável aos milhões de pés de alguns cafeicultores de Ribeirão Preto, como o Coronel Francisco Schmidt, que em 1905 contava em suas fazendas com 6.075.500 cafeeiros, ou a Companhia Dumont, com 3.999.990 de pés no mesmo ano, ou ainda Martinho Prado Júnior, que possuía 2.112.700 de cafeeiros também em $1905 .^{4}$

\footnotetext{
${ }^{2}$ Entendemos o complexo cafeeiro como um conjunto de atividades integradas entre si, tais como: comércio de exportação e importação, transporte ferroviário, produção de alimentos, ensacamento, beneficiamento, constituição de uma infra-estrutura urbana, financiamento, enfim, todas as atividades necessárias à produção e comercialização do café, nucleadas pela produção cafeeira e que se incrementaram mutuamente, reforçando o ritmo da acumulação.

${ }^{3}$ Sérgio Milliet, confrontando-se com a impossibilidade de se qualificar as propriedades produtoras de café por suas dimensões territoriais, dada a imprecisão de seus limites geográficos devido à fatores ligados ao processo de demarcação das terras que seria escusado tentar explicitar aqui, procede a uma classificação com base no número de pés de café: até 20 mil eram pequenas; acima de 20 até 50 mil eram médias; mais de 50 até 250 mil eram grandes; mais de 250 mil eram latifúndios Milliet (1938) apud (Messias, 2003, 72). Azzoni (1975) apud (Messias, 2003, 72) deparou-se com o mesmo problema em Araraquara e acabou por utilizar a classificação de Milliet por número de pés. Não utilizaremos nenhum tipo de classificação parecido aqui, pois para nossos objetivos o fundamental é diferenciar uma cafeicultura que operava apenas com trabalho familiar de toda produção acima de certo nível que exigia a contratação de mão-de-obra.

${ }^{4}$ Preto (1914). Arquivo Histórico Municipal de Ribeirão Preto.
} 
Esta característica da cafeicultura de Franca deriva em parte de sua estrutura fundiária e em parte ao tipo de solo predominante na região, o lato-solo vermelhoamarelo fase arenosa, que, diferentemente da terra roxa, não apresentava uma grande fertilidade para a cultura cafeeira. A estrutura fundiária de Franca, não tão concentrada como em outros municípios de maior produção cafeeira, originou-se de duas circunstâncias: em primeiro lugar da antiguidade do povoamento da região - por entrantes de pequenas posses, que a predispôs a uma maior fragmentação do solo; em segundo lugar ao fato de seus solos não se adequarem tão bem quanto os de terra roxa $^{5}$ à cafeicultura, não atraindo grandes investidores interessados em se estabelecer em grandes fazendas, como ocorreu em Ribeirão Preto no caso, por exemplo, de Martinho Prado Júnior. ${ }^{6}$

O desenvolvimento da cafeicultura de Franca não se repetiu o padrão verificado em Ribeirão Preto, não se pode, naquela localidade, partir da premissa de que grandes investidores estavam à frente da produção cafeeira. ${ }^{7}$ Do ponto de vista dos homens detentores de grandes capitais Franca constituía uma espécie de periferia no conjunto dos municípios paulistas produtores de café, e nunca, na sua história, se destacara pelo volume de sacas produzidas.

Em uma realidade dominada marcadamente pelas pequenas e médias propriedades - já que volumes na casa dos milhões de cafeeiros plantados, necessária e suficientemente, requeriam grandes propriedades para a sua plantação - como se constitui a economia cafeeira? São múltiplas as questões a serem consideradas, iniciemos pelas relações de trabalho. A cafeicultura local atinge escalas de produção capitalista na década de 1890 , conforme podemos verificar no gráfico que se segue. Se atentarmos para 0 fato de que Franca recebe uma ligação férrea em 1887, concluiremos que a inauguração da Estação da Mogiana na cidade tornou-se imprescindível para viabilizar o aumento da produção cafeeira.

Também na década de 1890 atinge maiores proporções a vinda de imigrantes para o município,

${ }^{5} \mathrm{Na}$ verdade a ocorrência da chamada terra roxa é rara no território paulista. O derrame de lavas basálticas ocorrido na bacia do Paraná foi o mais extenso do globo, com uma área estimada entre 800.000 e $1.000 .000 \mathrm{Km}^{2}$. Esparrama-se por boa parte dos estados de São Paulo, Santa Catarina, Paraná e Rio Grande do Sul, entretanto, cabe salientar a existência de uma alternância entre a sedimentação do arenito e derrames basálticos (lavas), estruturando o relevo em camadas (trata-se aqui de um vulcanismo de fissura, ou seja, as lavas basálticas irrompiam através de falhas e fraturas, inundando rapidamente as depressões existentes nos lençóis de areia, formando amplos lagos de rocha fundida que, ao consolidar-se, transformavam-se em vastas planícies negras. Esses derrames basálticos migravam de um para outro sistema de fraturas, devido ao tipo de atividade vulcânica que os originou, aflorando de maneira descontínua na superfície). Sob condições climáticas diversas ao longo do tempo geológico, as rochas basálticas provenientes desses derrames se transformaram num solo que, embora pobre em recursos minerais, é de excelente qualidade agrícola - a terra roxa (...). Devido ao afloramento ocasional das camadas, os solos de terra roxa legítima (diabásios, meláfiros calcíferos e basáltitos), também chamada de encaroçada, resultado do intemperismo das rochas basálticas, ocupam áreas esparsas constituindo as conhecidas "manchas de terra roxa". Sua ocorrência varia de 2,0\% a 2,5\% no território paulista, ou seja, de 5.000 a $6.000 \mathrm{Km}^{2}$. É encontrada somente nas vertentes onde afloram as camadas de basalto; mais raramente nos planaltos. São os solos característicos de Cravinhos, Ribeirão Preto e seus arredores, com terrenos que propiciam o desenvolvimento da cafeicultura.

${ }^{6}$ Também colaborou para esta fragmentação a inexistência ou o pequeno número de casamentos consangüíneos tal qual ocorreu na vertente de povoamento que Lucila Brioschi e outros (Brioschi, 1991, 72) chamaram de Rio Pardo (na região onde hoje se encontra o município de Ribeirão Preto e outros), onde estes parecem haver funcionado como uma estratégia de se manter a propriedade no interior do grupo familiar, permitindo a sua concentração ao longo do tempo. Na verdade este é um assunto muito complexo e que exigiria estudos específicos e mais aprofundados, mas é inegável a maior fragmentação da estrutura fundiária de Franca em comparação a outras.

${ }^{7}$ Segundo os dados de José Francisco de Camargo em 1905 a média de cafeeiros por propriedade era de 84.324 em Ribeirão Preto, 80.029 em São Carlos, 44.490 em Campinas, 29.973 em Jaú e 18.276 em Franca. Evidentemente existiam pequenas unidades produtoras de café em todos estes municípios, entretanto, nos casos de Ribeirão Preto, São Carlos e Campinas, as grandes propriedades "puxavam" a média de cafeeiros por estabelecimento para cima, o que não ocorria em Franca, corroborando nossa hipótese de que neste município, pelos motivos acima expostos, não existiam grandes fazendas em termos de produção cafeeira, por isso, uma reduzida média de pés de café por estabelecimento se comparada a outros municípios. Não se trata da inexistência da pequena cafeicultura em Ribeirão Preto, Campinas e São Carlos, mas da inexistência de grandes lavouras em Franca. Para destacar o caráter periférico da cafeicultura francana no cenário do "oeste" paulista, apresentamos o número de cafeeiros cultivados nestes municípios em 1905: 29.094 .365 em Ribeirão Preto, 28.518.100 em Campinas, 24.049.365 em São Carlos, 22.749.494 em Jaú e 7.380.988 em Franca. (Camargo, 1981, 92-133). 
destacando-se os italianos que em grande medida alocaram-se nas fazendas de café como colonos. Como Franca não se mostrou propícia ao surgimento de grandes lavouras cafeeiras também não atraiu grandes levas de imigrantes em comparação a outras regiões mais bem dotadas de recursos naturais. De fato, enumerar os municípios mais procurados pelos imigrantes seria simplesmente repetir a lista dos centros cafeicultores na ordem de sua importância, entre 1901 e 1920, Franca recebera 7.065 imigrantes, número que não se compara os 22.987 imigrantes registrados em Jaú no mesmo período e muito menos aos 37.149 registrados em Ribeirão Preto (Camargo, 1981, 40-2), salientando o fato de que também na década de 1890 a cafeicultura destes municípios amplia-se consideravelmente.

Figura 1 - Café embarcado na estação Franca da Mogiana 1888-1917

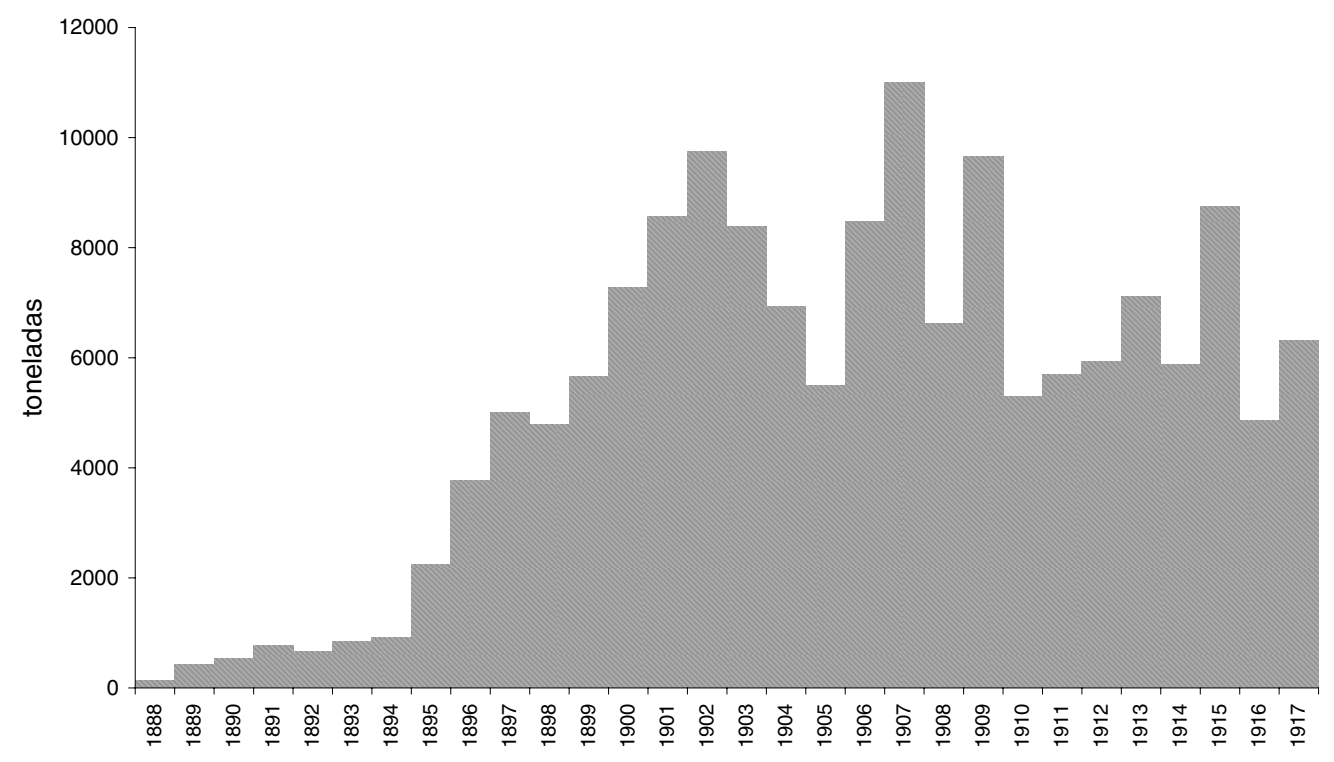

Fonte: Adaptado de Tosi 2003, p. 303.

Em que medida as relações de trabalho estabelecidas em Franca divergem ou convergem com as estabelecidas em outras regiões? Na verdade elas convergem, verifica-se em Franca, assim como em outros locais, a predominância do colonato. O que é o colonato? É quase unânime a resposta. Stolcke (1986), Holloway (1984), Sallum Jr. (1982) e Martins (1979) o definem como uma combinação de salário anual, ganhos por empreitada e acesso às lavouras de subsistência. Nas palavras de Sallum Jr. no colonato "as pessoas se comprometiam, por contrato, a realizar certo número de tarefas pelas quais recebiam remuneração em dinheiro. Basicamente tais tarefas consistiam em: cultivo anual de certo número de pés de café, pelo qual recebiam uma remuneração em dinheiro, variável segundo o número de pés e paga em parcelas trimestrais, bimestrais ou mensais, participação na colheita, pela qual auferiam dinheiro conforme a quantidade apanhada e entregue; serviços extraordinários, à parte do cultivo do cafezal e da colheita, pelos quais recebiam segundo o tempo de trabalho - dias ou horas - ou, eventualmente, conforme as tarefas executadas" (Sallum Jr., 1982, 145-67). Constitui-se o colonato na soma de três formas: trabalho anual, empreitada e acesso a terrenos para plantio de alimentos. As duas primeiras são monetárias, a segunda entrava como um paliativo para o rebaixamento dos gastos monetários 
com os trabalhadores.

Sob as condições acima descritas dava-se a contratação de trabalhadores para "tocarem" o café nas fazendas. Os contratos de trabalho eram registrados nos cartórios de registro civil, nestas escrituras definiam-se as formas de remuneração, o acesso à terra, o local e a autorização de plantio de outras culturas tais como o arroz, o milho e o feijão, o prazo de duração, os termos de garantia, adiantamentos. Na pesquisa realizada por Faleiros (2002) foram analisadas 270 escrituras de contratos de café entre 1866 e 1920, destas, 128 foram registradas entre 1890 e 1900, período ápice da cafeicultura local.

O sistema de colonato sempre se estabeleceu em áreas de fronteira, notadamente onde está em jogo a formação de novas lavouras. Observando-se os contratos constatamos que ao decidir formar uma nova lavoura os fazendeiros reduziam os seus gastos permitindo aos colonos o acesso a terra. Do ponto de vista do fazendeiro ceder terras aos colonos significava certa autonomia em relação ao movimento dos preços, uma vez que se diminuía a composição monetária da renda do colono; em momentos de preços altos da saca do café aumentava-se a renda dos fazendeiros, em momentos de baixa, mesmo com a renda deprimida, estes poderiam continuar formando novas lavouras, pois, na base, gastos monetários se efetivavam reduzidamente. O monopólio da terra garantia a sobrevivência e até mesmo a expansão das lavouras de café mesmo em cenários não satisfatórios. Observemos, na figura 2 , a evolução do número contratos de trabalho no tempo:

Figura 2 - Contratos de formação e/ou trato de café lavrados em Franca 1866-1920.

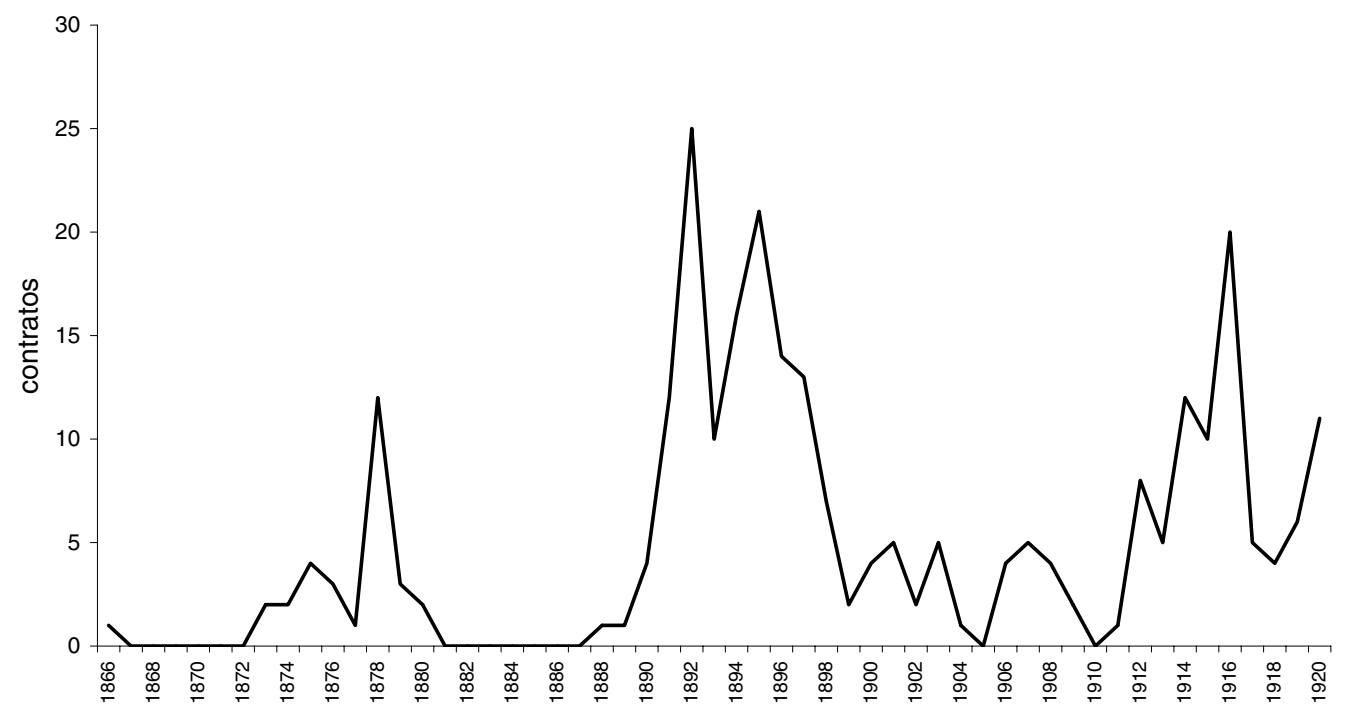

Fonte: Adaptado de Faleiros 2002, p. 24.

Pensemos: Qual é custo para se formar uma nova lavoura de café? Na década de 1890 o governo paulista subsidiava as passagens transatlânticas, bem como a hospedagem inicial e o transporte ferroviário até as fazendas que demandavam trabalhadores. Lá chegando, os trabalhadores eram alocados nas casas de colônia, em alguns casos, os próprios trabalhadores construíam as casas, arranchando-se em moradias precárias nas primeiras semanas. Cada núcleo familiar, em contrato, assumia um talhão, 
onde se responsabilizava pela formação e trato de alguns milhares de cafeeiros. Autorizava-se o plantio intercafeeiro e, ao final de quatro ou cinco anos, pagava-se uma determinada quantia por cada cova formada. É o caso de Jácomo Zulcarelli, que foi contratado em 1896 por Luiz Pinto Bastos para formar 12.000 cafeeiros, recebendo $0 \$ 700$ por cada cova formada ao final de quatro anos (Faleiros, 2002, 189), ou seja, uma quantia total de 8:400\$000 ao término do contrato, além de, teoricamente, dispor de toda a produção dos cafeeiros no quarto ano e da totalidade da produção de alimentos. Perceba-se que ao final de quatro anos o fazendeiro teria uma lavoura adequadamente formada e em plena produção com um mínimo custo monetário.

Os doze mil pés formados seriam viavelmente produtivos por pelo menos quinze anos. Considerando a produtividade dos cafeeiros francanos, estimada em 154,02 arrobas por mil pés em 1902, e considerando a cotação em Santos de $4 \$ 200$, apontada por Thomas Holloway para o mesmo ano, Luiz Pinto Bastos receberia 7:762 $\$ 608,{ }^{8}$ ou seja, em apenas um ano de colheita arcaria praticamente com todas as despesas de formação dos doze mil pés, restando, para o seu bolso, toda a produção daqueles cafeeiros nos próximos quatorze anos. Não era necessário ser um grande proprietário para se formar lavouras deste calibre.

Do ponto de vista do colono, e de sua família, por suposto, dedicar-se a outras culturas significava garantir a sua subsistência, além do que poderia capacitá-lo a atuar no mercado, vendendo os excedentes de sua produção alimentícia (milho, feijão, banha, toucinho e arroz) no meio urbano ou mesmo nas mercearias existentes no meio rural. Geralmente o colono também tinha direito à produção dos cafeeiros no último ano de contrato, o que pouco pesava nas suas contas, pois a produtividade de cafeeiros entre quatro e cinco anos de idade ainda não atingira todo o seu potencial.

Parte da bibliografia liga as possibilidades de ascensão social dos colonos à mercantilização do excedente de alimentos por eles cultivados. Nas palavras de Thomas Holloway:

Em muitos casos, os cereais e animais excedentes que o colono vendia proporcionavam uma importante fonte adicional de dinheiro. Tal renda extra podia ser adicionada às economias ou usada para comprar os itens não produzidos na fazenda, tal como farinha de trigo, açúcar, querosene, roupas e ferramentas. Como exemplo da importância que os próprios trabalhadores atribuíam ás porções não monetárias do contrato de trabalho, um Vice-Cônsul italiano em Ribeirão Preto constatava, em 1903, que os colonos preferiam uma fazenda onde os salários em dinheiro eram pequenos, mas onde os privilégios de lavoura de alimentos e criação de animais eram generosos, a uma fazenda onde os salários eram melhores, mas sendo restritos os privilégios não monetários. Um observador francês anotava em 1909: "o que realmente permite que os colonos acertem o deve e o haver são as plantações que eles tem o direito de fazer por sua própria conta... Eles muitas vezes se preocupam mais com as cláusulas do contrato relacionadas com essas plantações do que com aquelas que determinam seus salários em dinheiro" (Holloway, 1984, 122. Grifos nossos).

Segundo Faleiros seria um mito acreditar que os colonos disporiam livremente do café e dos alimentos por eles produzidos. O autor identifica o que poderíamos chamar de um "estreitamento de mercado" na comercialização dos excedentes produzidos pelos colonos. Complexos mecanismos atuavam no sentido de impedir os colonos de praticar os preços vigentes na praça, pois os fazendeiros interpunham-se entre estes e os compradores estabelecendo nos contratos de café cláusulas que garantiam a "preferência de venda" dos gêneros alimentícios à fazenda. Estas cláusulas foram encontradas na maioria

${ }^{8}$ É necessário destacar que se trata apenas de uma grosseira inferência, pois não consideramos os gastos com transporte, ensacamento, armazenamento, etc. Também não consideramos a atuação de intermediários, que drasticamente reduziam os valores recebidos pelos fazendeiros. Por outro lado, consideramos a cotação do ano de 1902, acentuadamente deprimida em relação ao passado por conta da crise de superprodução. De qualquer forma, acreditamos que os cálculos feitos acima demonstram, ainda que de forma aproximada, a alta lucratividade proporcionada aos fazendeiros que estabeleciam o regime de colonato. 
das quase trezentas escrituras pesquisadas pelo autor. Como exemplo, podemos citar o caso de Manuel Alves de Souza, que em 1893 foi contratado por José Theodoro de Mello para formar 12.000 cafeeiros na Fazenda Palmital. ${ }^{9}$ Nos quatro anos de contrato o colono teria direito à prática do cultivo intercafeeiro, entretanto, não poderia comercializar livremente a sua produção de alimentos, pois a escritura assinada por ambos determinava a "preferência de venda" a José Theodoro de Mello. Isto, numa sociedade hierarquizada onde o chefe da fazenda reunia em torno de si um grande número de agregados, entre eles os novos colonos, significava dizer que o trabalhador necessariamente teria que vender sua produção de alimentos ao proprietário.

A relação entre ambos tornava-se lucrativa ao fazendeiro sob dois aspectos: por um lado, ele garantia a formação de uma nova lavoura de café, e por outro concentrava a comercialização dos alimentos produzidos pelos colonos, numa relação cujas bases eram o monopólio do mercado e o estreitamento das relações de troca sendo a finalidade o enriquecimento via intercâmbios desiguais. Tinha-se, então, um mecanismo onde o colono, na terra intercafeeira, promovia a sua subsistência, mas perdia o excedente, ou sua maior parte, ao "negociá-lo" com o fazendeiro. Feito isto, este vendia os produtos no mercado e lucrava com a inequivalência dos preços. Ao contrário de Holloway, é dificil imaginar que os preços correntes no mercado orientassem as negociações estabelecidas entre fazendeiros e colonos.

Corrobora este argumento o fato de que as quantidades de alimentos embarcadas na estação Franca da Mogiana cresceram consideravelmente na medida em que a cafeicultura avançava no município. Se os colonos realmente se encarregassem da colocação de arroz, milho, feijão, etc. no mercado nos depararíamos com uma rede comercial pulverizada, onde múltiplos produtores participariam dos jogos das trocas. Contudo, observamos justamente o contrário:

A figura 3 acima posicionado revela que as quantidades de alimentos "exportadas" pelo município foram crescentes a partir da década de 1890. Certamente estes alimentos foram cultivados por colonos nos espaços intercafeeiros, revelando que o próprio crescimento das lavouras de café proporcionava o incremento da produção de outras culturas. Chegou-se a "exportar" quase três mil toneladas de gêneros alimentícios em 1898, mas tal volume de comércio não se realizaria se não fosse amparado e precedido por uma intensa concentração destas redes mercantis. Certamente os comerciantes e as Casas Comerciais sediadas na cidade constituíam o elo final de toda uma cadeia que se iniciava com a produção dos colonos, passava pelas mãos dos fazendeiros para, ao fim e ao cabo, chegarem aos agentes urbanos que escoavam esta produção até os centros consumidores de maior vulto.

Possuímos ainda um indício empírico da centralização do comércio de alimentos operada pelos fazendeiros de café. No inventário de Joaquim Garcia Lopes da Silva Júnior, ${ }^{10}$ datado de 1911, notamos que em suas três fazendas: Santa Amélia, Jaguarão e dos Buritys, o inventariado possuía uma certa quantidade de cereais estocados; na Santa Amélia 500 sacos de arroz avaliados a 5:500\$000, 25 carros de milho avaliados por $425 \$ 000$ e 80 sacos de feijão que montavam a 160\$000; no Jaguarão 8 carros de milho na roça a $200 \$ 000,7$ carros de milho no paiol a $245 \$ 000$ e 20 sacos de feijão ainda por colher a 40\$000; nos Buritys 30 carros de milho no paiol a 1:050\$000.

Wilson Cano afirma que a produção mercantil de alimentos é um componente prioritário na formação e consolidação do complexo cafeeiro. Segundo o autor a agricultura de alimentos era totalmente dependente da atividade nuclear, o café, e, portanto possuía autonomia muito relativa. Estava vinculada, em síntese, às sobras e aos tempos sobrantes de recursos semi-utilizados pelo café. Entendida dessa forma vê-se que seu desenvolvimento tendia a um limite ditado pela atividade nuclear. À medida que o complexo cafeeiro se desenvolvia e gerava um processo crescente de urbanização, o sistema reclamava também, ainda segundo Cano, a expansão da agricultura independente da atividade nuclear, ou seja, aquela que é feita fora da propriedade cafeeira, operando com os seus próprios recursos físicos (Cano, 1998, 72). O autor pressupõe que o crescimento das cidades demandaria "indústrias agrícolas"

\footnotetext{
${ }^{9}$ Livro de Notas N. 56, folha 84-6. $1^{\circ}$ Oficio Civil de Franca. (Faleiros, 2002, 184).

${ }^{10} \mathrm{Cf}$. Inventário de Joaquim Garcia Lopes da Silva Júnior. Caixa 139 do Tabelionato de $1^{\circ}$ ofício, 1911, volume 66, Arquivo Histórico Municipal de Franca. (Teodoro, 2006, cap. III)
} 


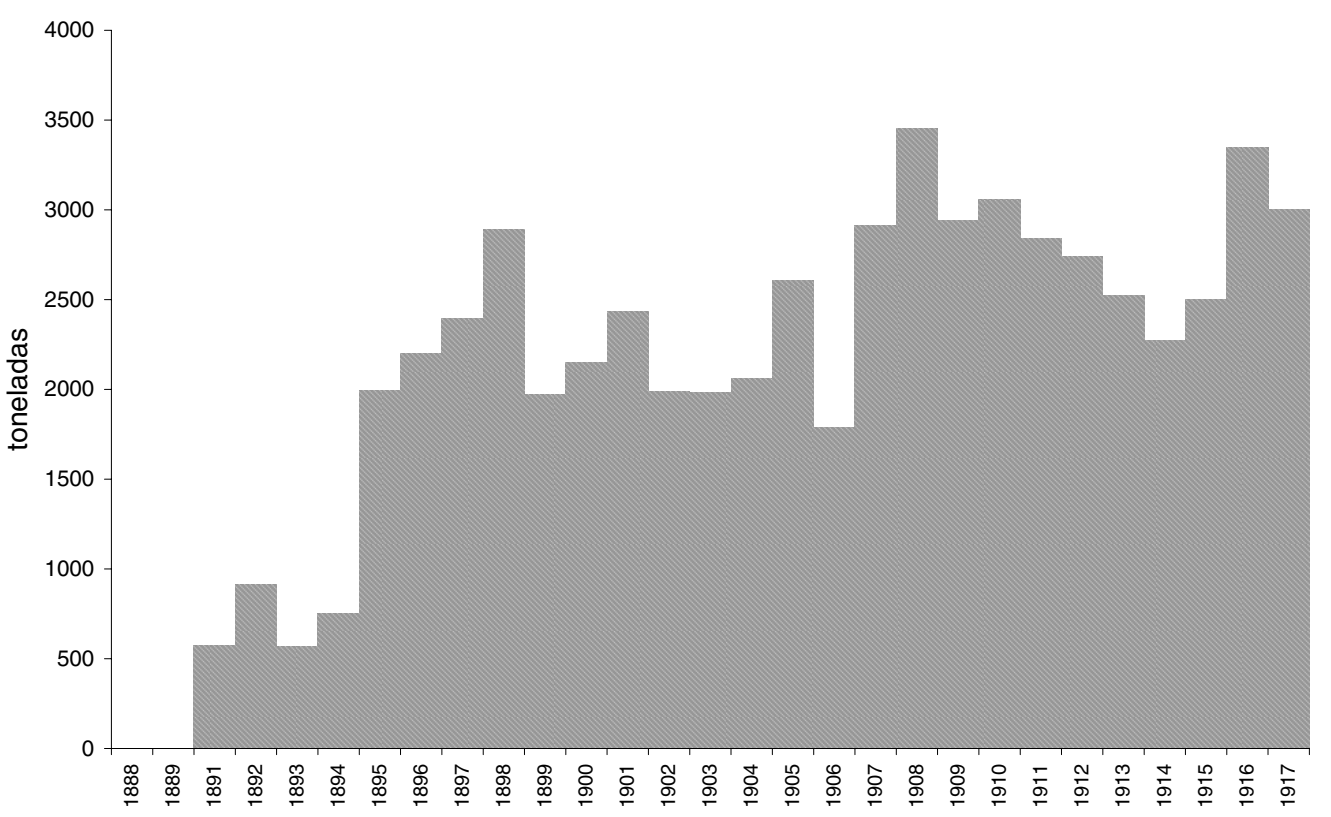

Fonte: Adaptado de Tosi 2003, p. 90.

especializadas na produção de alimentos, notadamente pequenas propriedades que se dedicariam ao cultivo de milho, arroz e feijão. Acreditamos que esta realidade pode ser verificada nos municípios da Grande São Paulo, tais como Mogi das Cruzes e Santa Izabel, principais abastecedores de alimentos da capital, entretanto não acreditamos que tenha existido uma separação rígida entre unidades produtoras de café e unidades produtoras de alimentos no "Oeste Paulista" tal como sugerido pelo autor. O caso de Franca, bem como de Campinas, Ribeirão Preto, Rio Claro, São José do Rio Preto e Catanduva, onde algumas pesquisas cartoriais realizadas por Faleiros (2005), demonstram que mesmo em período mais avançado ao aqui tratado, o cultivo conjunto do café e outros gêneros alimentícios foi largamente utilizado, notadamente na fronteira.

Mas se já colocamos em questão o que seria a principal possibilidade de acumulação dos colonos e, por conseguinte, à ascensão a condição de proprietário, como explicar o surgimento da pequena e mesmo da propriedade fundiária de dimensões diminutas, já que estas, em grande parte da bibliografia, (Camargo, 1981, Vol. I) têm por origem a frugalidade e a diligência pessoal dos trabalhadores do café, notadamente os imigrantes? Esta origem se aclara, no entanto, se nos voltarmos para os impactos da conhecida crise de superprodução que se abateu sobre a lavoura cafeeira no final do século XIX.

Os impactos da crise de superprodução fizeram-se sentir nas relações de trabalho estabelecidas entre fazendeiros e colonos naquele contexto. Segundo Augusto Ramos a situação da lavoura paulista era mais difícil, do ponto de vista financeiro, do que a dos demais produtores; em São Paulo predominava o colonato, enquanto nos demais estados predominava a parceria: "em São Paulo o preço do trabalho do colono é ajustado por mil cafeeiros no tratamento dos mesmos, por alqueire de 50 litros de café no trabalho de apanha, e por dia nos serviços avulsos (...) ele aufere também indiretamente vantagens 
de outra ordem e de maior valor. São as que resultam da cultura de cereais, feijão, etc., entre as filas dos cafeeiros. (...) Em outras regiões como a fluminense e Minas Gerais é freqüente serem as lavouras confiadas às famílias de colonos pelo sistema de trabalho por porcentagem ou parceria das colheitas, em geral a meias, isto é, cabendo a cada família, como remuneração por cuidar dos cafeeiros e fazer a colheita, metade do que esta produzir".(Ramos, 1923, 204-5).

Essa diferença regional implica que os valores financeiros envolvidos eram previamente estabelecidos em uma forma de trabalho e em outra não. Na parceria, dominante em Minas e no Rio de Janeiro, a remuneração do colono estava submetida à realização do valor mediante as condições do mercado, já os fazendeiros paulistas, por contratarem previamente as cláusulas envolvendo dinheiro submetiam-se ao descompasso entre a quantia envolvida na relação com o colono e o preço de mercado, o que, no contexto de superprodução, significava que os fazendeiros de São Paulo, como um todo, estavam acumulando prejuízos, fato atenuado nas terras de fronteira onde a produtividade equilibrava um pouco mais as contas.

Sob um outro aspecto as relações de colonato também pressionavam os cafeicultores. As terras para o plantio de outros alimentos eram fornecidas na proporção do cafezal envolvido na negociação, e uma vez que lavouras novas não estavam sendo formadas os fazendeiros não tinham condições de fornecer aos colonos novas terras para estes plantios. Tal argumento baseia-se no fato de que o colonato é uma relação de trabalho própria de um contexto de expansão das lavouras. 0 colonato pressupõe 0 movimento da fronteira.

Isso significa que o mecanismo de acesso à terra, ora antes usado para rebaixar os custos monetários, estava ficando "engessado", aumentando para os colonos a importância das cláusulas envolvendo dinheiro, justamente o que faltava nos anos de Campos Salles como presidente (1898-1902). No colonato a queda do preço do café recaía inteiramente sobre o fazendeiro-proprietário; na parceria era dividida, e mesmo que não fosse lucrativo ficar com apenas metade da produção, era positivo o fato de não assumir dívidas maiores com os colonos. Convenhamos, num momento de superprodução efetuar pagamentos com café aos colonos (parceria) constituía uma funcional estratégia utilizada pelos fazendeiros. Em conseqüência da crise o número de contratos de formação e/ou trato de café em Franca diminuiu drasticamente (ver figura 2). Ao mesmo tempo os cafeeiros plantados no início da década de 1890 atingiram o ápice de produtividade, exportando-se quase dez milhões de toneladas em 1902.

No auge da crise, em 1905, não foi lavrado nenhum contrato de trabalho. As exportações de café reduziram-se a pouco menos de seis milhões de toneladas, chegando ao ponto máximo da decadência iniciada em 1903. Em 1906, com a intervenção estatal, o número de contratos lavrados começou novamente a subir, a exportação de café acompanhou este movimento, marcando a recuperação das lavouras prejudicadas anteriormente com a geada de 1902.

As conseqüências do período de retração 1898-1905 redimensionaram as propriedades em Franca. Múltiplas falências foram registradas no contexto da política deflacionária de Murtinho, ministro de Campos Salles. As maiores plantações do município foram praticamente varridas do mapa. Custos elevados e preços cadentes resultaram no abandono e desvalorização das propriedades, bem como em movimentação de trabalhadores em direção às zonas novas. Interessantes são os números apontados por Pedro G. Tosi:

No que concerne ao fracionamento e reconcentração das propriedades rurais no período em tela [1905-1920], interessa qualificar que houve um continuado decréscimo no tamanho médio das propriedades: de 159 alqueires em 1905 para 110 em 1920. (...). O número

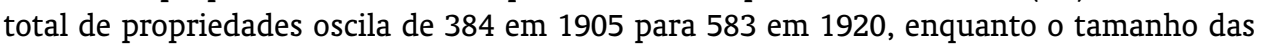
propriedades foi sendo diminuído. Apesar disso, aumentava o número total de cafeeiros plantados, bem como a área cultivada, embora nem sempre fosse crescente a média de cafeeiros por estabelecimento. (Tosi, 2003, 144)

O que os dados deste autor evidenciam é um verdadeiro fenômeno de fragmentação da propriedade; os cafeicultores de maior porte, atingidos em cheio pela crise desfizeram-se de porções de terras para 
saldar suas dívidas e ainda, segundo o autor, "foi no período entre 1906 e 1915 que imigrantes, principalmente de origem espanhola e italiana, credores de dívidas para com os velhos cafeicultores, dotados de alguma economia e famílias numerosas, tiveram acesso à propriedade de terras de dimensões não muito elevadas. Começaram, então, a aparecer os sitiantes e pequenos fazendeiros de origem estrangeira. O produto, contudo, não deixara de ser a base da economia local: já em 1915, em virtude da mudança na estrutura fundiária, era possível verificar o aumento do número de cafeeiros".(Tosi, 2003, 138)

\section{CRÉDITO E ACUMULAÇÃO: O PAPEL DA PEQUENA CAFEICULTURA}

Até aqui explicitamos a forma como operavam as médias propriedades e o contexto em que se dá o surgimento das pequenas, estas baseadas, em geral, no trabalho familiar. Mas de imediato outra questão se coloca: qual a funcionalidade dessas pequenas propriedades no conjunto da economia cafeeira? Para chegarmos à raiz do problema, devemos analisar os movimentos próprios desta economia, de modo a privilegiar o processo de acumulação vis a vis às formas de financiamento dos produtores, pois se constitui em um setor vital para a compreensão desta dinâmica.

Cabe salientar, a partir do estudo de Flávio Azevedo Marques de Saes sobre o sistema bancário paulista na Primeira República, que os fluxos de crédito oriundos deste dificilmente se dirigiam à lavoura e que, na verdade, os grandes bancos nacionais sediados na cidade de São Paulo preferiam concentrar suas operações de empréstimos nos empreendimentos comerciais de algum porte que atuavam na própria capital e em Santos, dada a maior lucratividade, a maior solvência e, conseqüentemente, o menor prazo de retorno do investimento que estas atividades ofereciam em comparação à produção de café (Saes, 1986, 112-123). Os bancos estrangeiros, por sua vez, dedicavam-se ao financiamento da dívida pública, dos investimentos ferroviários e industriais. Os bancos do interior, em geral, eram inexpressivos no que diz respeito ao seu volume de capitais e, portanto, mais suscetíveis às intempéries próprias das flutuações da economia cafeeira. Os bancos hipotecários, por sua vez, eram poucos e comumente privilegiavam suas carteiras comerciais em detrimento dos empréstimos garantidos por hipotecas, principal modalidade de crédito utilizada pelos lavradores.

Assim, percebemos que os cafeicultores deveriam possuir acesso a alguma fonte de crédito não oriundo do sistema bancário, já que é difícil pensar num sistema de autofinanciamento dos fazendeiros, dada a natureza do cafeeiro, cujos frutos só aparecem após o quarto ou quinto ano de cultivo. A questão é: de onde provém este crédito? Devemos nos voltar agora para um personagem que a bibliografia têm apontado como fundamental para o financiamento da cafeicultura: o comissário.

O comissário surge como um intermediário entre o fazendeiro e o exportador na venda do café. Na verdade, o comissário não agia apenas como um mero representante comercial, embora inicialmente suas atividades tenham se restringindo a tal função. Também fornecia a seus clientes vários artigos oriundos dos grandes centros urbanos de que estes necessitavam, mas sua centralidade na economia cafeeira advinha da posição que ocuparam no fornecimento de crédito para a lavoura, que se impôs ao comissário praticamente como uma exigência para a prosperidade de seus negócios, já que o fazendeiro, conforme já ressaltamos, dificilmente dispunha de condições para se autofinanciar (Carvalho Franco, 1974, 160-171). Também percebemos a atuação, nas cidades do interior, além do comissariado, de uma camada de financistas locais que ficaram conhecidos como "capitalistas", denominação que denotava, na verdade, a posse de dinheiro disponível para empréstimos. Apesar da atuação porventura diferenciada que comissários e capitalistas possam ter apresentado e que não cabe aqui discutir havia algo em comum entre ambos e que trazia sérias conseqüências para a lavoura cafeeira: as altas taxas de juros cobradas e o curto prazo praticado nas operações de crédito como observamos nas figuras 4 e 5 .

Pode-se perceber, em ambos as figuras 4 e 5, uma melhora das condições de financiamento da lavoura no intervalo de 1907 a 1914. Ao lograr êxito na fixação dos preços do café em um patamar superior ao passado e acenar com possibilidades de uma maior estabilidade no movimento dos pre-

RBE Rio de Janeiro v. 61 n. 3/ p. 405-426 Jul-Set 2007 
Figura 4 - Prazos praticados nos empréstimos registrados em Franca por períodos selecionados

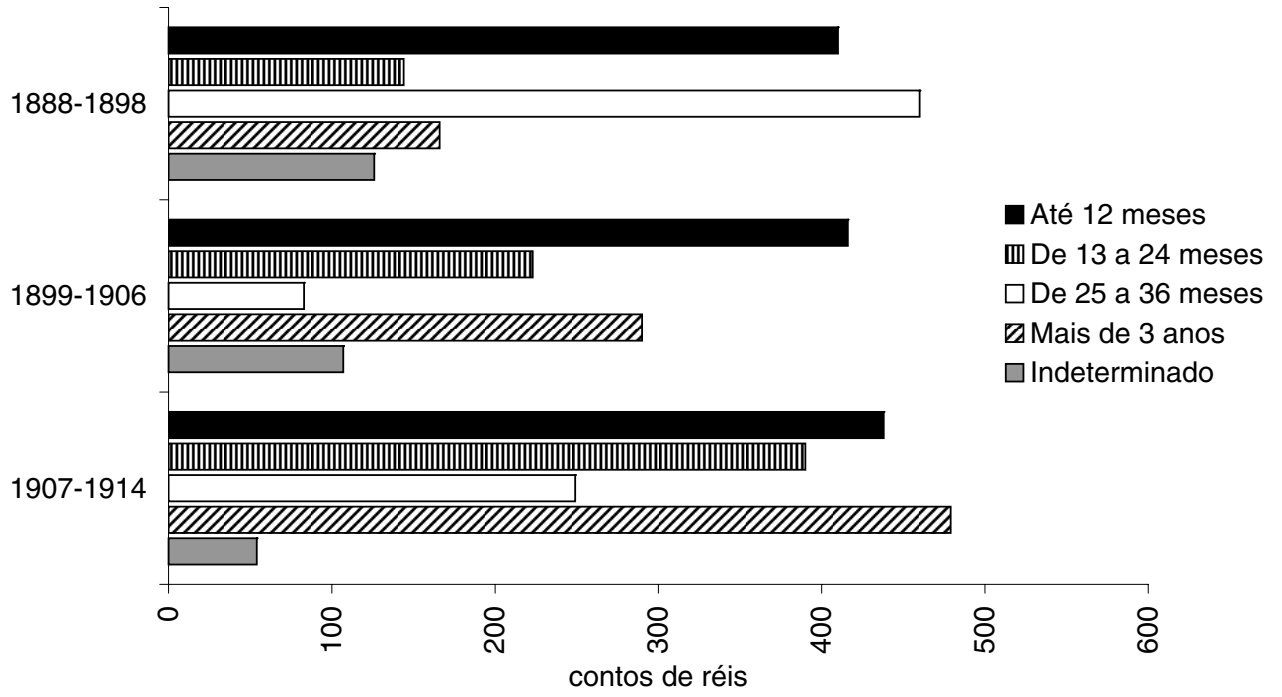

Fonte: Livros de Notas do $2^{\circ}$ Ofício Civil de Franca, 1888-1914. In: Teodoro 2006, p. 144

ços, o plano de valorização de 1906 garantiu maior segurança para os credores durante este período, permitindo o estabelecimento de prazos maiores e taxas de juros mais aprazíveis. Entretanto, o crédito continuava caro aos tomadores, pois nem de longe satisfazia as necessidades dos investimentos na cafeicultura que demandavam prazos mais dilatados, pois apenas registrariam lucros quatro ou cinco anos depois de realizadas as primeiras despesas.

O Banco de Crédito Real de São Paulo, fundado em 1882 e liquidado em 1906, por exemplo, emprestava a $8 \%$ para prazos de cinco a dez anos e $9 \%$ de quinze a vinte anos, apesar de uma série de exigências na efetivação do crédito que desestimulava a captação por parte dos cafeicultores (Saes, 1986, 70-1). Renato Leite Marcondes analisando as taxas de juros no Vale do Paraíba, identificou que em Lorena para os anos compreendidos entre 1850 e 1872 as taxas atingiam em média 16\% ao ano. Não obstante, o comportamento da taxa de juros, entre 1865 e 1887, parece apontar para uma progressiva redução, o que Marcondes atribui à penetração do capital bancário (Marcondes, 2002, 147-70). O autor percebe que durante a crise de $1874 / 1876^{11}$ as taxas de juros apresentam-se discrepantes entre o município de Lorena, onde aumentam, e Guaratinguetá onde se mantêm estáveis, provavelmente pela chegada do capital bancário nesta localidade antes que em Lorena. Na segunda metade da década de 1860 a taxa de juros para o crédito hipotecário chega a casa dos $14 \%$ ao ano nos dois municípios, vindo a oscilar entre 11 e 10\% entre 1879 e 1886, atingindo 9,5\% em 1887. Este exemplo também evidencia a discrepância das taxas de juros praticadas pelo setor institucionalizado (bancos) e o crédito informal (comissários e

\footnotetext{
${ }^{11}$ Conforme assinala Carlos G. Guimarães, bastou uma mudança na direção seguida pela política monetária para que todo o setor comercial e creditício da cidade do Rio sofresse sérios abalos. Visando valorizar o câmbio, o governo diminuiu a quantidade de papel-moeda emitido, cujo total (incluindo o papel-moeda posto em circulação pelos bancos), de um patamar de 192.527:000\$000 em 1870 passa a 181.868:000\$000 em 1875. (Guimarães, 2003, 02-9).
} 
Figura 5 - Taxas de Juros praticadas nos empréstimos registrados em Franca por períodos selecionados

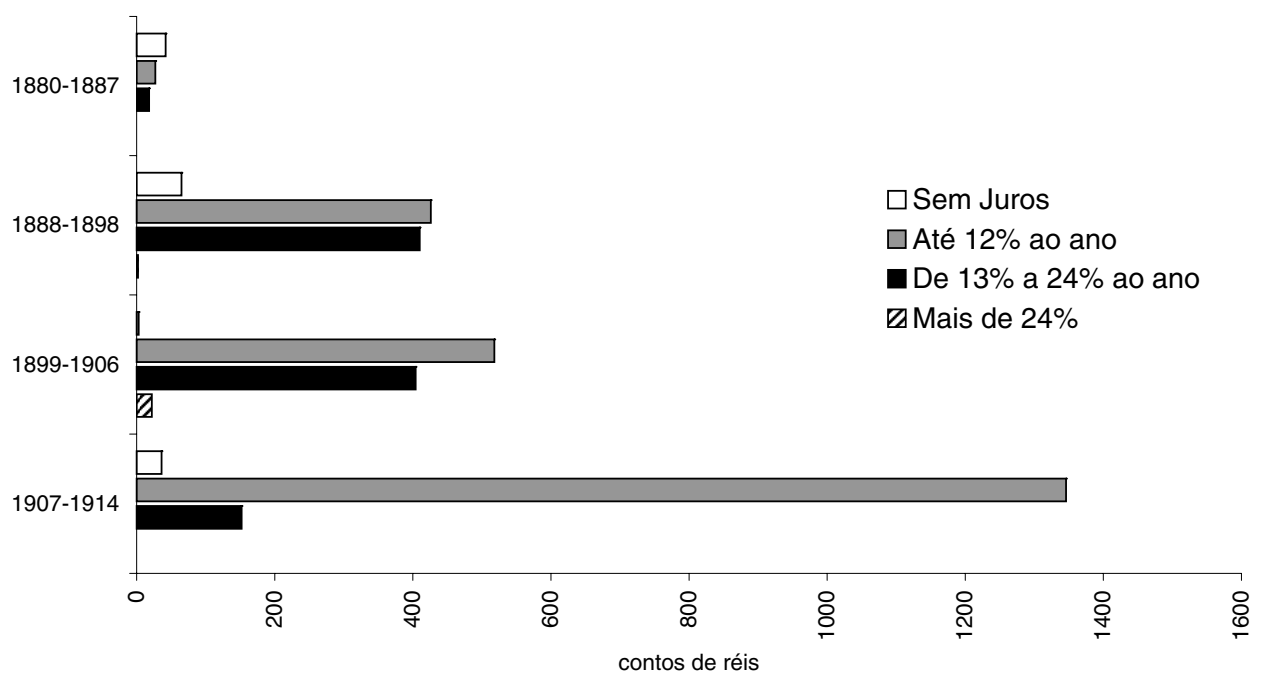

Fonte: Livros de Notas do $2^{\circ}$ Ofício Civil de Franca, 1888-1914. In: Teodoro 2006, p. 138

“capitalistas").

Os cafeicultores, contudo, não apenas sofriam o efeito das altas taxas de juros em suas contas, mas também se encontravam, ainda que indiretamente, expostos a todo o tipo de crise que porventura atingisse o sistema financeiro. A inexistência de um banco de redescontos ${ }^{12}$ implicava na manutenção, pelo sistema bancário, de uma elevada proporção de caixa para fazer frente às situações adversas, de modo que, segundo Saes, havia uma quantidade maior de dinheiro em poder do público que nas instituições bancárias. Esta estrutura, associada à centralidade do grande capital cafeeiro ${ }^{13}$ nesta economia, conferia uma enorme fragilidade ao sistema bancário em contextos em que atuavam conjuntamente dificuldades de realização do café no mercado internacional, crise nas contas públicas e políticas contracionistas, muitas vezes derivadas da postura governamental frente à própria conjuntura econômica. Como havia a possibilidade dos comissários e "capitalistas" captarem recursos junto ao sistema bancário, uma carência de numerário deste, poderia repercutir sobre a cafeicultura. É neste sentido que uma política de "enxugamento" do meio circulante se espraiava pelo conjunto econômico.

Destarte, é bastante compreensível que a cafeicultura possa se expandir e mesmo encontrar alguma facilidade em saldar seus débitos em uma conjuntura de abundante liquidez, inflação de preços e desvalorização cambial - já que esta permitiu a manutenção ou mesmo a ampliação da renda em moeda

\footnotetext{
${ }^{12}$ Redesconto: operação bancária em que uma instituição financeira desconta títulos (duplicatas, promissórias, etc.) que já foram anteriormente descontados por outra instituição. É uma operação que permite, à primeira casa bancária, fazer caixa para novos negócios, sem ficar imobilizada à espera do vencimento dos títulos. (Sandroni, 1985, 363).

${ }^{13}$ Conforme a definição de Renato M. Perissinotto, o “Grande Capital Cafeeiro” engloba os agentes econômicos que se caracterizavam por uma larga diversificação de seus investimentos: comércio de exportação e importação, atividade bancária, indústria, estradas de ferro, empresas de serviços públicos, etc. (Perissinotto, 1994, 37-44).
} 
nacional dos agentes exportadores num contexto de queda dos preços internacionais do café - como foi o período conhecido como "Encilhamento", cujos efeitos se estenderam pelo menos até 1898, dado que o fazendeiro não apenas encontrava maior facilidade no acesso ao crédito como era auxiliado pela própria progressão da queda do câmbio e da depreciação do dinheiro no pagamento do empréstimo. Entretanto, como a cafeicultura conseguiu absorver os impactos da crise?

Como observamos na figura 1, a cafeicultura do município de Franca se ressentiu dessa crise de numerário, tanto que as quantidades de café embarcadas na estação Franca da Mogiana reduziram-se drasticamente a ponto de passarem de um patamar de cerca de 9.700 toneladas em 1902 para cerca de 5.500 toneladas em 1905. Contudo, já em 1906, ano no qual ainda não havia se dissipado os efeitos da superprodução acrescida da premente escassez de moeda que caracterizou o início do século XX, as quantidades embarcadas sobem para cerca de 8.500 toneladas, atingindo o ápice em 1907: 11.000 toneladas de café. Ora, não podemos atribuir este aumento nas quantidades embarcadas nos anos de 1906 e 1907 simplesmente aos cafeeiros formados antes de 1898, pois neste caso as quantidades produzidas nos anos imediatamente posteriores a 1902 equiparar-se-iam às quantidades produzidas neste. O que estamos tentando dizer é que se registra em 1907 uma quantidade de toneladas embarcadas maior do que em 1902, logo, pode-se inferir que cafeeiros foram formados durante a crise. Como explicar?

Os financistas locais por algum meio não sofreriam as conseqüências da falta de numerário promovida pelas políticas governamentais de teor contracionista que lhes permitisse seguir fornecendo crédito à lavoura? Ou seja, a escassez monetária atingiria também esta camada de usurários? Certamente. A figura 6 corrobora este argumento com dados empíricos.

Figura 6 - Volume de empréstimos efetivamente tomados em Franca 1889-1914. Dados Deflacionados

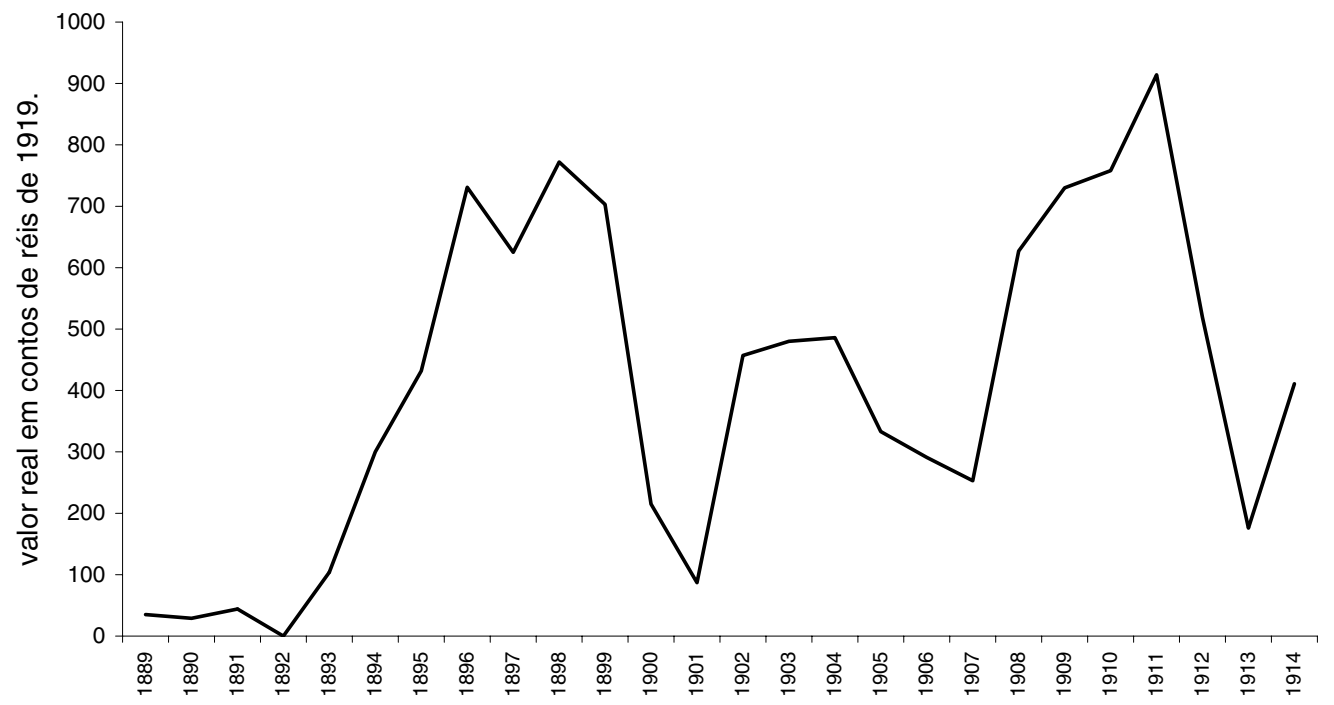

Fonte: Livros de Notas do $2^{\circ}$ Ofício Civil de Franca, 1880 a 1914, $\mathrm{n}^{\circ} 5$ ao 79. In: Teodoro 2006, cap. III. Valores deflacionados a partir de Villela e Suzigan 2001, p. 433

Permanece a questão: como é possível a expansão da cafeicultura mesmo com uma severa restri- 
ção creditícia? A mudança no regime de trabalho do colonato para a parceria, explica parcialmente a questão, mas como podemos perceber pela figura 2 , houveram poucos contratos de trabalho lavrados em cartório entre 1899 e 1911, demonstrando que esta não foi a via, ou a principal via, de expansão da lavoura cafeeira naquele período. Talvez um olhar mais atento sobre a estrutura do crédito elucide a questão. Observemos a figura 7 que se segue.

Figura 7 - Proporção dos créditos registrados em Franca por faixa de valor e períodos selecionados

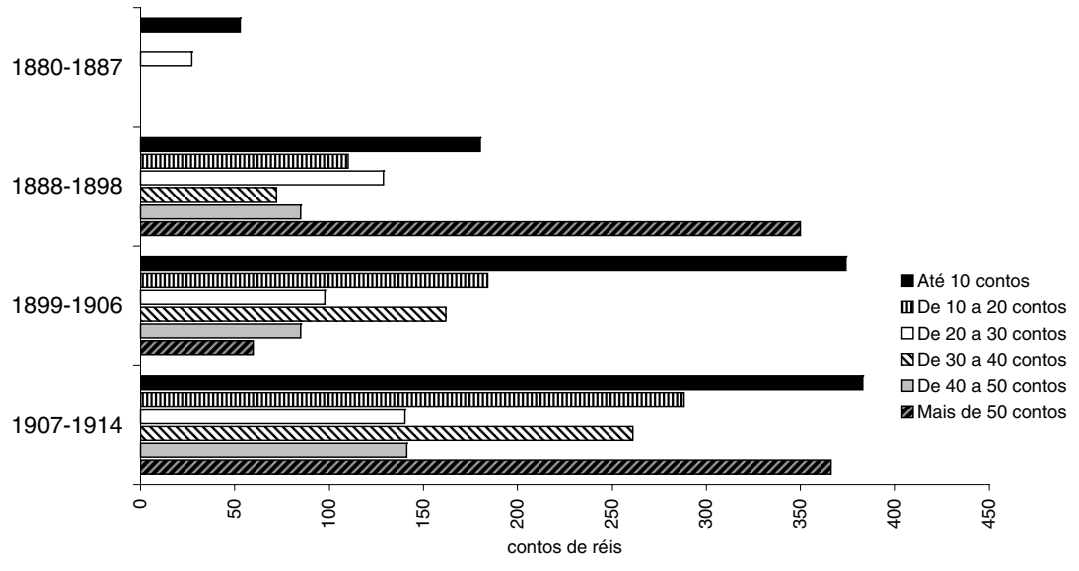

Fonte: Livros de Notas do $2^{\circ}$ Ofício Civil de Franca, 1880 a 1914, $n^{\circ} 5$ ao 79. In: Teodoro 2006, cap. III. Somamos o valor de todas as escrituras em cada faixa.

O que salta aos olhos no tocante ao período compreendido entre 1899 e 1906 é a abrupta elevação do valor total das escrituras de até 10 contos de réis e sua participação, mais uma vez em termos de valor, no total das operações creditícias registradas no período. Mas direcionar-se-ia este fluxo para a cafeicultura? Segundo Teodoro, do total de empréstimos no valor de até 10 contos efetuados entre 1880 e 1914 registrados no tabelionato de $2^{\circ}$ ofício de Franca, apenas 313:845\$534 ou 29\% das dívidas firmadas correspondiam aos lavradores enquanto devedores, de um total de 1.074:031\$902. Os comerciantes firmaram dívidas, considerando apenas estas quantias de até 10 contos, em um montante de 140:100\$480, ou 13\% do total. O restante dos empréstimos se referia a devedores com ocupação indeterminada, a um expressivo número de profissionais liberais e a elementos designados genericamente como "proprietários" (Teodoro, 2006, cap. III). Tanto estes "proprietários", quanto os devedores cuja ocupação não é discriminada nas escrituras caberiam na classificação de comerciantes ou de lavradores. Mas como analisá-los na falta de informações mais precisas?

Teodoro também ressalta que para estes empréstimos com valor de até 10 contos, a proporção de imóveis urbanos dados em garantia (34\%) praticamente se emparelha aos rurais (36\%) Se acrescermos a esta constatação o fato de que nos empréstimos de pequenas quantias onde a ocupação dos devedores definiu-os como lavradores, apenas $34: 085 \$ 800$ ou $11 \%$ se firmaram com garantia hipotecária de imóveis urbanos, concluiremos que o tipo de bem dado em garantia é um bom índice da ocupação do tomador. Assim se já sabíamos que a proporção de lavradores captando estes empréstimos era de $29 \%$ e de pequenos comerciantes $13 \%$ podemos dividir o restante entre ambas as categorias de devedores resultando em um montante de $58 \%$ para os pequenos proprietários rurais e $42 \%$ para os pequenos

RBE Rio de Janeiro v. 61 n. 3/p. 405-426 Jul-Set 2007 
proprietários urbanos.

Estes dados indicariam uma maior lucratividade da pequena cafeicultura? Teodoro, a fim de tentar dar uma resposta a esta questão, analisa as condições de alguns desses empréstimos, como o contrato registrado no $2^{\circ}$ tabelionato de notas de Franca no ano de 1900 entre o Dr. Marcílio Mourão, capitalista e Joaquim Antonio de Andrade, lavrador, onde aquele efetua um empréstimo a este no valor de 2:100\$000, a 1,5\% de juros ao mês com capitalização semestral (os pagamentos deveriam realizar-se de seis em seis meses) e garantia de 300 arrobas de café. Mas o importante nesta escritura reside no fato de o escrivão observar que o credor receberia 15 quilos pelo preço de 10 que vigorasse em Santos. ${ }^{14}$ No mesmo teor era o contrato entre Olívio Alves Ferreira, capitalista, e José Urias do Nascimento, lavrador, onde aquele emprestou a este a quantia de 6:000\$000 com a garantia sobre 900 arrobas de café que deveria entregar na estação Mogiana, limpo e beneficiado; o devedor pagaria uma arroba por cada 10 quilos, ou melhor, pagaria a dívida com cada arroba de café valendo 10 quilos. ${ }^{15}$ Analisando mais alguns contratos onde 0 beneficiamento do café ficaria a cargo do devedor, Teodoro demonstra que se os cafeicultores em geral encontravam-se numa posição de subordinação aos usurários urbanos, em maior grau estariam ainda os pequenos proprietários (Teodoro, 2006, cap. I).

Mas como se explica então o vigor demonstrado pela pequena propriedade? Analisando o inventário do mesmo Joaquim Antonio de Andrade ${ }^{16}$ que contratara empréstimo com Marćlio Mourão em 1900, Teodoro nota não apenas que o devedor realizara poucas despesas monetárias com o café (possuía 3 mil cafeeiros), já que não empregava nenhum trabalhador no trato deste, como também dedicava-se à produção de animais, possuía um pomar, além de haver a possibilidade de cultivar outros gêneros alimentícios, de modo a pelo menos no quesito subsistência estar bem suprido. Ademais, pelos dados constantes do inventário, a dívida com Marcílio Mourão chegou a 608\$620 em 1902, indicando que os herdeiros do devedor reuniam condições razoáveis de solvência, reduzindo o seu débito a menos de um terço do valor original em apenas dois anos. (Teodoro, 2006, cap. III).

Evidencia-se, portanto, que as pequenas propriedades produtoras de café, notadamente aquelas em que se utilizava apenas o trabalho familiar, ao contrário das médias e grandes propriedades, orientavam suas atividades primariamente para a subsistência e somente secundariamente para o mercado. Provavelmente se inseriam neste para conseguir acesso a alguns dos bens que não podiam produzir, como ferraduras, utensílios agrícolas, algum vestuário, etc. Se a pequena cafeicultura por um lado mostravase menos lucrativa que àquela de maiores proporções, por outro possuía um poder de sobrevivência muito maior, tanto que não apenas atravessa os anos de crise, mas a permanência de um expressivo número de operações de crédito situadas em um valor de até 10:000\$000 entre 1906 e 1914 denota que a pequena propriedade poderia coexistir com as médias e quiçá com as grandes.

Este fato reveste-se de importância ainda maior se analisarmos o outro ponto do circuito do crédito, ou seja, a oferta. Se observarmos a ocupação dos principais emprestadores que operavam em Franca ao longo do tempo, perceberemos que as fontes de financiamento eram sobretudo locais, como demonstrado na figura 8:

Pode-se notar que a participação dos "capitalistas", cuja principal atividade consistia exatamente no empréstimo a juros, situa-se sempre em altos patamares. Os lavradores - designação que possivelmente se referia na sua quase totalidade aos fazendeiros - forneceram crédito em um volume mais alto durante o período em que se sentiu com maior força os efeitos do encilhamento, denotando que sua atuação como fornecedores de dinheiro ligou-se sobretudo a uma conjuntura de abundância monetária. Negociantes e comerciantes emprestaram mais no momento da crise deflacionista que se instaurou com o advento das políticas de Joaquim Murtinho, provavelmente porque com a escassez de numerário os cafeicultores passaram a intensificar o recurso ao crédito nas suas compras de artigos citadinos, ou

\footnotetext{
${ }^{14}$ Livro de Notas n. 36, fls. 14. $2^{\circ}$ Oficio Civil de Franca. 1900. (Teodoro, 2006, cap. III).

${ }^{15}$ Livro de Notas n. 36, fls. $16.2^{\circ}$ Ofício Civil de Franca. 1900. (Teodoro, 2006, cap. III).

${ }^{16}$ Inventário de Joaquim Antonio de Andrade. Volume 58, Caixa 138, 1902, volume 58. Arquivo Histórico Municipal de Franca. (Teodoro, 2006, cap. III).
} 
Figura 8 - Proporção por ocupação nos créditos concedidos em Franca em períodos selecionados

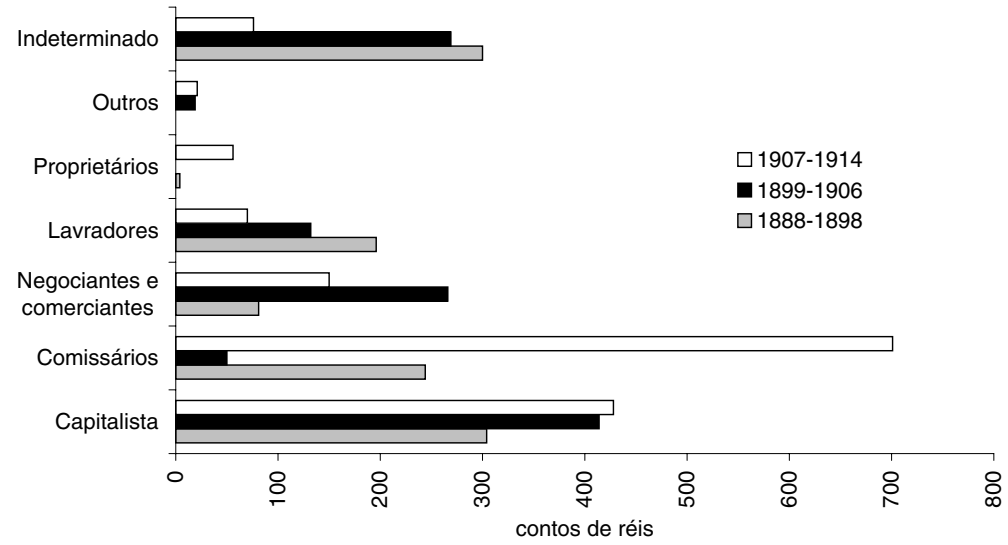

Fonte: Livros de escrituras do Tabelionato de $2^{\circ}$ oficio de Franca de 1880 a 1914, $n^{\circ} 5$ ao 79 . AHMF. In: Teodoro 2006, cap. III.

simplesmente porque durante a crise o comércio sentiu a necessidade de efetuar um registro dessas operações, necessidade não sentida em períodos anteriores. Todos estes credores aos quais já aludimos originavamse na quase totalidade da região de Franca, de forma que, salvo o comissariado, não havia emprestadores de dinheiro de fora do município realizando transações em âmbito local de modo expressivo.

O comissariado, ao contrário dos demais fornecedores de crédito, intensificam suas atividades em Franca apenas após o plano de valorização de 1906. Não nos compete aqui tentar explicar este comportamento, posto que buscamos apenas situar a pequena cafeicultura dentro de um quadro de expansão dos plantios e as relações da cadeia de crédito com todo este processo, mas cabe frisar que duas casas comissárias que atuaram entre 1907 e 1914, a Torquato Caleiro \& Cia. e a Silva Ferreira \& Cia., cujos empréstimos, em valor, corresponderam a $66 \%$ de todas as transações realizadas durante este mesmo subperíodo, possuíam, em seu quadro de sócios, comerciantes e "capitalistas" francanos. Na verdade a Torquato Caleiro levava o nome de um dos filhos de um eminente comerciante e capitalista local, o Coronel Simão de Oliveira Caleiro e operava em conjunção com a Hygino Caleiro, Sandoval \& Cia., estabelecimento mercantil de Franca dirigido por um dos irmãos de Torquato. A Silva Ferreira \& Cia. tinha entre seus sócios os irmãos Azarias Martins Ferreira e André Martins de Andrade (este representante da companhia em Franca), filhos do Coronel Francisco Martins Ferreira Costa, comerciante local de certo vulto, além de José Joaquim da Silva, também de Franca.

Esta vinculação das casas comissárias de maior porte a famílias do município permite deduzir que ainda que parcela do capital acumulado pela Silva Ferreira \& Cia. e pela Torquato Caleiro \& Cia. permanecesse na cidade de Santos, parte significativa poderia refluir para o município de Franca. Mas mais importante do que esta constatação é o fato de que estes comerciantes e capitalistas locais obtiveram lucro suficiente no período anterior ao plano de valorização para investirem em casas comissárias assim que assomasse uma conjuntura mais favorável. O item indeterminado que apresentamos na figura provavelmente se referia a emprestadores da região, já que a ocupação dos credores externos em geral aparece de forma muito bem especificada. Assim verificamos que o crédito fluía principalmente de 
fontes locais, estimulando a acumulação endógena de capital.

Temos apenas mais um reparo a fazer acerca da oferta de crédito. Encontramos, nas escrituras, 19 procurações para que terceiros levantassem empréstimos no Banco Real de Crédito de São Paulo entre 1895 e 1900 e a soma das quantias solicitadas montava a 2.670 contos. ${ }^{17}$ Embora esta quantia ultrapasse de longe o montante dos empréstimos registrados no livro cartorial de $2^{\circ}$ ofício de Franca para o mesmo período, tratava-se apenas de solicitações, havendo inclusive a possibilidade de que se fixassem as quantias pedidas em um patamar mais alto do que realmente se desejava. Ademais, com a documentação de que dispomos não há como saber se estes empréstimos se efetivaram na prática, mas a presença do Banco de Crédito Real de São Paulo em uma lista de cafeicultores do município de Franca de $1910^{18}$ (apesar de sua liquidação em 1906, o que não é de todo estranho se pensarmos que este processo poderia levar alguns anos) indica que pelo menos parte destas solicitações de financiamento devem ter se convertido em contratos de hipoteca e que na virtual insolvência dos devedores o banco executou suas propriedades. Isto parece demonstrar que se houve alguma participação direta do sistema bancário no financiamento da cafeicultura no município de Franca, esta se deu durante o período de maior abundância monetária, na década de 1890. Curiosamente, não se registraram mais procurações com este teor após o ano de 1900, apesar da liquidação do banco só ocorrer seis anos depois.

Portanto, sem a pequena cafeicultura e o pequeno comércio, provavelmente os grandes comerciantesusurários do meio urbano (dada a dificuldade de se distinguir com clareza como polarizavam ambas as atividades) que certamente concentravam os resultados da acumulação de capital nessa economia (Teodoro, 2006, cap. I e II), não poderiam manter um nível de lucratividade mínimo, sem o qual dificilmente se impediria a fuga destes capitais bem como o deslocamento das atividades desse estrato de financistas para outras regiões (talvez na fronteira?) e conseqüentemente a evasão de seus recursos. 0 papel da pequena cafeicultura torna-se ainda mais dilatado se pensarmos que o pequeno comércio citadino poderia se sustentar em parte devido ao consumo de artigos por setores do próprio meio urbano (como a ferrovia, que demanda uma série de empregados para funcionar e a produção de determinados artigos, ainda realizada em base artesanal) que desfrutavam de uma relativa autonomia em relação ao comportamento da lavoura cafeeira, mas também em razão do consumo dos pequenos lavradores e daquelas fazendas de café de maior porte que conseguiram sobreviver. ${ }^{19}$

Como os níveis de lucratividade dos agentes responsáveis pelo financiamento da lavoura cafeeira se mantiveram (ou ao menos não se reduziram drasticamente), as fazendas de maiores proporções, assim que o mercado cafeeiro acenou com uma conjuntura mais favorável a partir de 1907, puderam retomar a atividade cafeeira, seja por meio de novos investidores ou por meio de alguns proprietários de maior porte que conseguiram resistir à crise. Durante a crise, o sistema continuou funcionando devido às mudanças verificadas no circuito do crédito. Nossa análise documental evidencia a entrada do pequeno produtor e a prática do pequeno crédito neste circuito, contudo, isso não permite afirmar que todos os médios cafeicultores estivessem excluídos do sistema de crédito. Na medida em que as condições tornaram-se favoráveis, especialmente a partir do plano de valorização, o circuito de crédito pôde ser redirecionado às unidades de maiores proporções e de maiores escalas de produção, a despeito da continuidade das operações creditícias envolvendo pequenos produtores.

Frente às condições adversas da crise, muitos cafeicultores sucumbiram, entretanto, algumas estratégias de sobrevivência permitiram que alguns desses fazendeiros atravessassem o período compreendido entre 1898 e 1906. Nas fazendas de maior porte, numa conjuntura adversa, os custos geravam impactos extremamente negativos. Como alternativa de redução destes impactos, o que a documentação

\footnotetext{
${ }^{17}$ Livros de Escrituras do Tabelionato de $2^{\circ}$ oficio de Franca, $\mathrm{n}^{\mathrm{o}} 24,26,32,33,34,36,37,62$. AHMF.

${ }^{18}$ Cf. Vital Palma. Almanach de Franca: 1912. São Paulo: Salesianas, 1911, pp. 203 a 207. MHMF.

${ }^{19} \mathrm{Em}$ todo o complexo cafeeiro a presença dos pequenos produtores de café foi significativa, de modo que os mecanismos que expusemos aqui para Franca poderiam atuar também em outros municípios. A diferença é que grandes cafeicultores (inexistentes em Franca) poderiam resistir de forma diversa na crise, seja porque encontrassem menores dificuldades para diversificar seus negócios seja porque possuíssem maior patrimônio para queimar.
} 
consultada nos permite afirmar é que as formas de rebaixamento dos custos monetários na cafeicultura em crise foram sendo radicalizados. "É o caso de João de Pádua Pedroso, que ao contratar em regime de parceria os italianos Santo Baptistoni e Pio Dionísio, cedeu aos "parceiros" um alqueire de terra aonde poderiam plantar cereais, além de terras para a criação de gado e porcos". ${ }^{20}$ Esta escritura foi lavrada em 1902, num dos momentos mais críticos da superprodução, e, além da produção de alimentos, os colonos, durante quatro anos, teriam direito a metade da produção dos 13.000 cafeeiros. Mesmo sob a vigência de um sistema de parceria o trabalhador ainda poderia produzir outros gêneros alimentícios que não o café. De uma forma geral, os contratos de parceria versavam sobre lavouras já formadas, o que certamente reduziria a possibilidade de os colonos praticarem o cultivo de alimentos nos espaços intercafeeiros, entretanto, nestes casos, o fazendeiro cedia um terreno extra para compensar tal perda.

Nos contratos de colonato, mesmo utilizando-se de vários elementos para reduzir os gastos em dinheiro necessários à formação das lavouras, conforme vimos acima, alguma quantia, mesmo que diminuta, era gasta. Entretanto, na escritura acima citada, o fazendeiro não desembolsaria nenhum dinheiro (exceto eventuais adiantamentos, compra de ferramentas, remédios, produtos de armazém, etc.), além do que liquidaria seus débitos com o colono com a metade da produção de café, produto com preços altamente deprimidos naquele contexto. Com a parceria os cafeicultores desfaziam-se de dois problemas: reduziam seus gastos monetários necessários à manutenção da lavoura e livravam suas "tulhas" de estoques indesejáveis. Foram estas as estratégias utilizadas pelos cafeicultores para minimizar a perda patrimonial que se seguiu à superprodução do final do século XIX e às políticas contracionistas implementadas a partir do governo Campos Salles.

Mesmo assim, após 1898, os cafeicultores de maior porte ainda deveriam saldar as dívidas firmadas no período anterior, e, a fim de minimizarem a perda de patrimônio, tentar expandir a parcela dos lucros que lhes cabia. Além do monopsônio na compra dos alimentos produzidos pelos trabalhadores, que outras formas havia de incrementar os ganhos do cafeicultor?

Em uma dissertação de mestrado sobre a atuação de Costa Machado, um eminente cafeicultor de São José do Rio Pardo, Fábio Augusto Missura nos mostra alguns casos em que o fazendeiro conseguia levar adiante suas atividades econômicas sem o uso ostensivo da moeda. Analisando 140 cadernetas de contas de colonos de uma das fazendas de Costa Machado, a Vila Costina, entre 1891 e 1892, demonstra uma situação de endividamento de todos estes para com o fazendeiro, endividamento oriundo principalmente dos gastos dos trabalhadores no armazém da fazenda. Mas o colono não poderia escapar a esta armadilha simplesmente buscando adquirir os artigos de que precisava de outras fontes, como os comerciantes da cidade? Vejamos o que afirma Missura: "Os colonos tinham liberdade para fazerem suas compras onde preferissem. o fazendeiro, por sua vez, procurava controlar o monopólio de seu negócio, evitando que nenhum concorrente se estabelecesse na vizinhança. Na fazenda Vila Costina desenvolveu-se um artifício bastante curioso como forma de manter o colono preso ao armazém e à farmácia (havia uma farmácia dentro da fazenda): criou-se uma espécie de moeda interna, que o colono recebia como vale; como esse vale dificilmente era aceito na cidade o trabalhador não tinha outra alternativa a não ser gastá-lo no armazém da própria fazenda"(Missura, 2003, 46-7).

Neste ponto observamos duas formas de achatar os custos monetários das operações de uma fazenda de café: primeiro superexplorando os colonos, posto que na medida em que se atinge um monopólio mercantil em relação a estes, abre-se ao cafeicultor a possibilidade de elevar sobremaneira 0 preço dos produtos vendidos a seus empregados impingindo uma situação de endividamento que dificilmente se contornaria; segundo dispensando a utilização de moeda nas relações entre o fazendeiro e seus colonos. Entretanto, se pensarmos no conjunto das relações travadas pelo cafeicultor, devemos nos indagar sobre a forma como este obtinha os produtos que vendia em seu armazém. Há apenas uma possibilidade: estes produtos saíam diretamente dos estabelecimentos comerciais das cidades para a fazenda, o que exige mais uma pergunta: como o fazendeiro pagava por estes artigos? Certamente que se tratavam de compras a prazo, mas até que ponto o comerciante poderia esperar pelos pagamentos em

\footnotetext{
${ }^{20}$ Livro de Notas n. 86, fls. 35-7. $1^{\circ}$ Ofício Civil de Franca. 1902. (Faleiros, 2002, 192).
} 
moeda? Na verdade nestas transações havia mais uma forma de se minimizar o uso da moeda, que consistia em trocar alguns gêneros produzidos pelos colonos, como arroz, feijão e milho, por mercadorias que estes mesmos colonos necessitavam. (Teodoro, 2006, cap. III).

A citação que extraímos do trabalho de Fábio Missura, evidentemente, refere-se a uma grande propriedade, situada em São José do Rio Pardo, contudo não sabemos se estes procedimentos de estreitamento monetário se efetivavam também nas fazendas de médio porte. Existe a possibilidade, por exemplo, de alguns "vendeiros", ligados a fazendeiros ou não, organizarem o jogo das trocas num pequeno raio de ação que incluiria médias e pequenas propriedades. Mas mesmo que houvesse a possibilidade da efetivação desses estreitamentos monetários para os médios proprietários individualmente considerados, muitos, por não possuírem patrimônio para queimar, ou por já se encontrarem por demais onerados por dívidas contraídas no período anterior, não conseguiriam escapar dos efeitos da crise. A partir de 1897/1898 percebemos, nas escrituras de contratos de café, que a transição das relações de colonato para as de parceria já estava em curso (Faleiros, 2002, 190-1), ainda que uma parcela dos fazendeiros optassem por dar continuidade às remunerações em dinheiro, talvez temendo as multas estabelecidas nos contratos de colonato. Portanto, a superação da crise, para cada cafeicultor dependia de sua situação anterior de endividamento, da extensão de seu patrimônio e mesmo de suas decisões de investimento.

\section{CONSIDERAÇÕES FINAIS}

Ao final do percurso esperamos ter logicamente explicitado o papel fundamental assumido pela pequena cafeicultura ${ }^{21}$ na sustentação e viabilização do complexo cafeeiro, em especial nos momentos de dificuldades de realização da produção. Adotamos aqui uma visão de conjunto, buscando rastrear os pontos de contato entre a produção, a circulação e a acumulação, bem como as formas pelas quais as pequenas propriedades se inseriram em tal circuito. Ao adotar uma visão de conjunto múltiplos desafios se colocaram, entre eles, rastrear as dificuldades enfrentadas pelas propriedades de maior porte, levando-nos diretamente a analisar o mundo da produção, que ao contrário dos ruídos provocados pela circulação, em geral oculta seus movimentos. Dificil perceber as realidades vivenciadas entre fazendeiros e colonos no espaço circunscrito pela porteira uma vez que as relações travadas entre ambos foram marcadas por arranjos que extravasavam as cláusulas registradas em contrato.

Dificil também é perceber os pontos de contato destas relações com um conjunto econômico mais amplo, dificuldade que só pode ser superada quando nos defrontamos com a acumulação de capital e nos deparamos com a figura dos comissários e usurários urbanos, que tal qual o fazendeiro, em seu próprio espaço, estabeleciam, na cidade, no processo de financiamento da lavoura, uma relação, aonde, agora, o fazendeiro tornavase o expropriado.

As dificuldades aumentam ainda mais quando se percebe o silêncio da bibliografia em relação ao universo da pequena cafeicultura. Como eram financiadas? Como produziam? Este silêncio precisa ser superado, pois a pequena propriedade esteve presente no cenário rural do complexo cafeeiro. Nada mais fizemos aqui do que eleger um espaço aonde esta fora preponderante, o que nos possibilitou observá-la de forma mais clara. Possivelmente o peso da pequena cafeicultura tenha sido considerável também em outros municípios, existindo aí a possibilidade de estudos futuros.

Geralmente a questão da pequena propriedade aparece na bibliografia relacionada à da ascensão social dos imigrantes, notadamente italianos, residindo aí o marco inicial de uma estrutura fundiária mais fragmentada. Discordamos desta afirmação para o caso estudado, pois percebemos, pelas evidências coletadas, que os imigrantes submetiam-se a desvantajosos contratos de trabalho e reuniam poucas possibilidades de angariar algum pecúlio, principalmente em momentos de crise.

Paradoxalmente, é justamente na crise onde se percebe um processo mais acelerado de fragmentação da terra, ligado mais às dificuldades dos fazendeiros do que à frugalidade, ética ou capacidade de

\footnotetext{
${ }^{21}$ Notadamente aquelas nas quais se utilizava apenas o trabalho familiar e que não possuíam mais que 15.000 cafeeiros.
} 
poupança dos colonos. Mesmo quando o colono imigrante (ou não) tornava-se proprietário a pequena cafeicultura, como demonstramos, reunia parcas possibilidades de acumulação, pois se submetia ao julgo dos usurários num grau de exploração ainda mais elevado do que o praticado com os grandes proprietários. É necessário distinguir acesso à terra de ascensão social, uma coisa não necessariamente implica em outra, pequenos proprietários, no que tange ao "enriquecimento", talvez enfrentassem dificuldades maiores do que alguns colonos, notadamente daqueles situados na crista da fronteira, aonde as condições de produtividade do café e do cultivo alimentício intercafeeiro eram superiores.

\section{Referências Bibliográficas}

Brioschi, L. R. (1991). Entrantes no sertão do Rio Pardo: o povoamento da Freguesia de Batatais século XVIII/XIX. CERU, São Paulo.

Camargo, J. F. d. (1981). Crescimento da população no estado de são paulo e seus aspectos econômicos. Technical Report I, II e III, IPE/USP, São Paulo.

Cano, W. (1998). Raízes da concentração industrial em São Paulo. IE/UNICAMP, Campinas.

Carvalho Franco, M. S. (1974). Homens livres na ordem escravocrata. Ática, São Paulo, 2 edition.

Dean, W. (1976). A pequena propriedade dentro do complexo cafeeiro: sitiantes no município de rio claro, 1870-1920. Revista de História, 53(106):47-94.

Faleiros, R. N. (2002). Homens do café: Franca 1880-1920. Dissertação de mestrado, IE/Unicamp, Campinas.

Faleiros, R. N. (2005). Fronteiras do Café: Fazendeiros e colonos no interior paulista (1917-1937). Tese de Doutorado, IE/Unicamp, Campinas. Relatório Parcial de Pesquisa FAPESP n. 01 (mimeo).

Font, M. (1985). Padrões de ação coletiva dos plantadores paulistas de café: 1932-1933. In Economia e movimentos sociais na América latina. Brasiliense, São Paulo.

França, A. (1960). A marcha do café e as frentes pioneiras. Ed. do Conselho Nacional de Geografia, Rio de Janeiro.

Guimarães, C. G. (2003). O banco rural e hipotecário do rio de janeiro e o pós-guerra do paraguai, 1871-1875. Anais do V Congresso Brasileiro de História Econômica e $6^{\text {a }}$ Conferência Internacional de Históri 031, ABPHE - Associação Brasileira de Pesquisadores em História Econômica (Brazilian Economic History Society). available at http: //ideas.repec.org/p/abp/he2003/031.html.

Holloway, T. H. (1984). Imigrantes para o café: café e sociedade em são paulo 1866-1934. Paz \& Terra, 70.

Marcondes, R. L. (1998). A pequena e a média propriedade na grande lavoura cafeeira do vale do paraíba. LOCUS, 4(02):35-54.

Marcondes, R. L. (2002). O financiamento hipotecário da cafeicultura no vale do paraíba paulista (186787). Revista Brasileira de Economia, 56(01):147-70.

Martins, J. d. S. (1979). o cativeiro da terra. Livraria Editora de Ciências Humanas, São Paulo.

Mello, J. M. C. d. (1982). O Capitalismo Tardio: contribuição à revisão crítica da formação e do desenvolvimento da economia brasileira. Editora Brasiliense, São Paulo, 8 edition. 
Messias, R. C. (2003). O cultivo do café nas bocas de sertão paulista: mercado interno e mão-de-obra no período de transição - 1830-1888. Editora Unesp, São Paulo.

Milliet, S. (1939). Roteiro do café e outros ensaios. Coleção do Departamento de Cultura, XXV(29).

Missura, F. A. (2003). Costa machado: ação política e empresarial na sociedade do café em rio pardo (1877-1917). Dissertação de mestrado, UNESP/FHDSS, Franca.

Monbeig, P. (1984). Pioneiros e fazendeiros de São Paulo. Hucitec, São Paulo.

Oliveira, L. L. d. (1997). Economia e História: Franca século XIX. UNESP/FHDSS: Amazonas S/A, Franca.

Perissinotto, R. M. (1994). Classes Dominantes e Hegemonia na República Velha. Editora da Unicamp, Campinas.

Preto, R. (1914). Almanach Illustrado de Ribeirão Preto. Sá, Manaia \& Cia, Ribeirão Preto. Não paginado. Arquivo Histórico Municipal de Ribeirão Preto.

Ramos, A. (1923). O café no Brasil e no Estrangeiro. Papelaria Santa Helena, Rio de Janeiro. Contribuição comemorativa do $1^{\circ}$ Centenário.

Rossini, R. E. \& Oliveira, R. M. d. (1999). Sociedade e natureza. In Na estrada do Anhanguera. Uma visão regional da história paulista, pages 25-33. Humanitas FFLCH/USP, São Paulo.

Saes, F. A. M. d. (1986). Crédito e Bancos no desenvolvimento da economia paulista: 1850-1930. IPE/USP, São Paulo.

Sallum Jr., B. (1982). Capitalismo e cafeicultura. Oeste Paulista 1888-1930. Duas Cidades, São Paulo.

Sandroni, P. (1985). Dicionário de Economia. Abril Cultural, São Paulo.

Silva, S. (1986). Expansão Cafeeira e Origens da Indústria no Brasil. Editora Alfa-Omega, São Paulo, 7 edition.

Stolcke, V. (1986). Cafeicultura: Homens, Mulheres e Capital. (1850-1980). Brasiliense, São Paulo.

Teodoro, R. d. S. (2006). O crédito no mundo dos senhores do café. franca 1885-1914. Dissertação de mestrado, IE/UNICAMP, Campinas.

Tosi, P. G. (2003). Capitais no interior: Franca e a história da Indústria coureirocalçadista (1860-1945). UNESP/FHDSS, Franca.

Vangelista, C. (1991). Os braços da lavoura: imigrantes e "'caipiras"' na formação do mercado de trabalho paulista (1850-1930). Hucitec/Instituto italiano de cultura / Instituto cultural ítalobrasileiro, São Paulo. Tradução: Thei de Almeida Viana Bertorello.

Villela, A. V. \& Suzigan, W. (2001). Política do governo e crescimento da economia brasileira 1889-1945. IPEA/INPES, Rio de Janeiro, 3 edition. 